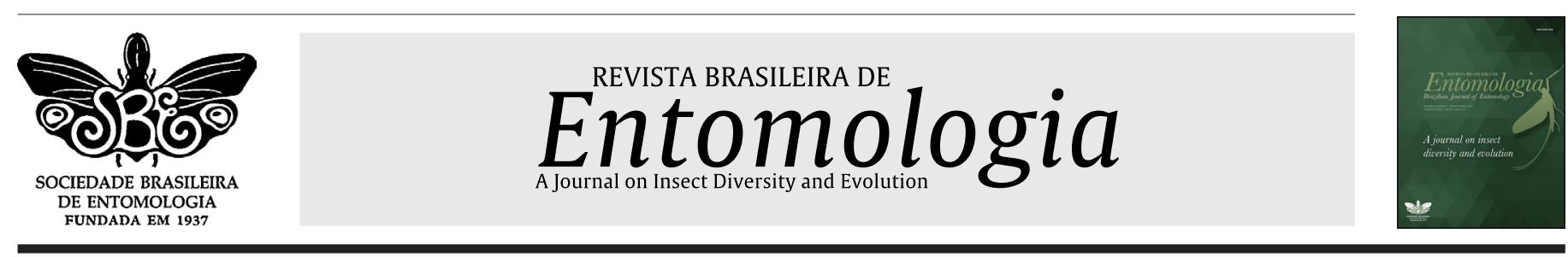

\title{
Temporal variation and spatial distribution of the pest insect Edessa meditabunda in cotton (Gossypium hirsutum) as an alternative host plant
}

\author{
Rafael Azevedo da Silva ${ }^{*} \oplus^{\oplus}$, Paulo Eduardo Degrande ${ }^{\circledR}(\mathbb{C}$, Matheus Dalla Cort \\ Pereira $^{2}$ (1), Ellen Patrícia de Souza ${ }^{2}$ (1)
}

${ }^{1}$ Instituto Federal de Mato Grosso do Sul, Nova Andradina, Brasil, MS, Brasil.

${ }^{2}$ Universidade Federal da Grande Dourados, Faculdade de Ciências Agrárias, Dourados, MS, Brasil.

\section{A R T I C L E I N F O}

\section{Article history:}

Received 16 March 2021

Accepted 16 June 2021

Available online 16 July 2021

Associate Editor: Regiane Cristina Bueno

\section{Keywords:}

Brown-winged stink bug

Cotton agroecosystems

Infestation

Mapping

Sampling

\begin{abstract}
A B S T R A C T
Cotton is an alternative host for Edessa meditabunda (Hemiptera: Pentatomidae), especially after the soybean harvest in surrounding areas, when large numbers of insects invade cotton fields and damage reproductive structures such as flowers and developing bolls. However, no studies on its occurrence and spatial distribution have been conducted in cotton. Therefore, this study was aimed to assess the temporal variation and spatial distribution of E. meditabunda in the alternative host plant, Gossypium hirsutum. The study was carried out in an area of 1.1 ha planted with cotton that was divided in 64 plots of $169 \mathrm{~m}^{2}$ each, where entire cotton plants were examined weekly and $E$. meditabunda nymphs and adults were counted. Dispersion rates and theoretical frequency distributions were calculated and analyzed with significance level at $5 \%$. Assessments were carried out from seedling emergence until the appearance of bolls, but E. meditabunda was present only during the reproductive stage of cotton plants. This study detected the dispersal of this stink bug from late-cycle soybean fields to cotton, indicating cotton's potential as an alternative host plant, providing shelter and food. Based on aggregation indices, the spatial distribution of nymphs and adults in cotton was aggregated at the beginning of the infestation, but tended toward randomness as bolls reached maturity. The occurrence of E. meditabunda in cotton was best described by the Poisson distribution with significance level at $5 \%$.
\end{abstract}

\section{Introduction}

The stink bug Edessa meditabunda (Fabricius, 1794) (Hemiptera: Pentatomidae) is a Neotropical insect pest associated with many species of Solanaceae and Fabaceae, as well as cotton, eggplant, tobacco, sunflower, papaya, and grapes. In addition, its abundance has increased in soybean fields, particularly in the central-west region of Brazil (Panizzi, 2015).

The distribution of $E$. meditabunda in the Neotropics includes Argentina, Brazil, Paraguay, and Uruguay in South America, while in the Caribbean, it has been recorded in Barbados-Antigua, Cuba, Dominican Republic, and St. Vincent (Panizzi, 2015).

Phytophagous stink bugs of the Pentatomidae family have been considered occasional pests and of secondary importance in cotton in Brazil in the last few years. However, they are being frequently reported in significant numbers in Brazilian cotton-growing areas (Soria et al., 2009). This can be explained by the fact that when soybean is harvested and cotton fields are in proximity, the latter serves as shelter and food source, providing the conditions to support stink bugs until their

\footnotetext{
* Corresponding author.

E-mail: rafael.silva@ifms.edu.br (R.A. Silva).
}

preferred host plant is available (Azambuja et al., 2015). Therefore, the management of stink bugs in cotton agroecosystems is a major concern in several countries in the Americas (Sosa-Gómez et al., 2019).

In addition, the importance of phytophagous stink bugs of the Pentatomidae family to cotton crops has increased in Brazil as the number of insecticide applications in this crop was reduced with the introduction of the Bt technology and the success of regional programs to control the boll weevil (Anthonomus grandis) (Soria et al., 2009; Lu et al., 2010). Similar results have been observed in the Mid-South and Southeast regions of the USA in the mid-1990s (Haney et al., 2009; Olson et al., 2011).

The dispersal of stink bugs to cotton fields is critical when soybean plants are maturing, normally coinciding with cotton reproductive stages (emission of flower buds, flowers, and boll formation), thus directly impacting fiber quality (Soria et al., 2009). According to Bundy and McPherson (2000), phytophagous stink bugs infest cotton mainly in its reproductive stage, from the first flowers until the formation of the first bolls, with show no preference for structures in other developmental stages. 
In cotton, stink bugs are associated with boll shedding, pathogen inoculation, and boll rotting, in addition to lint staining and immaturity, thus reducing yields and fiber and seed quality (decrease of $60 \%$ of cotton seed and lint production) (Medrano et al., 2007; Reay-Jones et al., 2009; Soria et al., 2010).

Studies have shown that $E$. meditabunda is the most invasive stink bug attacking cotton fields and has the potential to invade this crop and cause significant damage (Soria et al., 2009; Azambuja et al., 2015), despite not being the most frequent species (Sosa-Gómez et al., 2019).

Reliable sampling is therefore needed to determine the population density of this pest as well as to assess damage intensity over time to improve sustainable pest management in cotton (Farias et al., 2001). Characterizing the spatial distribution of $E$. meditabunda is the first step to establish sampling plans, aimed at reducing sampling time, increasing the reliability of results (Grigolli et al., 2012), and accurately describing the occurrence of this pest in the field (Fernandes et al., 2018).

Based on these results, species distribution can be described as aggregate, uniform, or random, but requires confirmation by adjusting the theoretical frequency distribution of the number of individuals for each species and for each specific crop.

We do not have studies examining the temporal and spatial distribution of $E$. meditabunda in cotton, with most of the available information on its distribution in soybean (Fonseca et al., 2017 and Fernandes et al., 2018). Therefore, the present study aimed to examine the temporal variation and horizontal spatial distribution of $E$. meditabunda in cotton.

\section{Materials and methods}

The study was conducted at the Experimental Farm of Agricultural Sciences of the Federal University of Grande Dourados (Fazenda Experimental de Ciências Agrárias da Universidade Federal da Grande Dourados - FAECA/UFGD), located in the municipality of Dourados-MS,

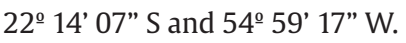

The experimental field was sowed with 910 Fibermax ${ }^{\circledR}$ cotton seeds, with spacing of $0.76 \mathrm{~m}$ between rows, totaling 12 plants per linear meter. The management of diseases and weeds was carried out according to agricultural practices recommended for the crop (Freire, 2015).

The experimental area consisted of 1.1 ha of cotton field surrounded by soybean fields and divided into 64 plots of $13 \times 13 \mathrm{~m}$. Each plot was identified numbering them from 1 to 64 and distributed in a spiral in the study area, sharing the same type of soil and following the same fertilization regime. In the central area of each plot, two plants were examined weekly throughout the development of the crop, starting at 7 DAE (Days After Emergence) of cotton seedlings until 150 DAE. The aerial parts of cotton plants were carefully bent laterally and thoroughly examined, and the number of $E$. meditabunda nymphs and adults were visually counted.

The abundance of nymphs and adults obtained was used to characterize temporal and spatial variation of stink bugs. E. meditabunda individuals were found in five of the 17 evaluations carried out, between 55 DAE and 91 DAE, which were used to calculate the mean, variance, and aggregation indices. In addition, the following theoretical frequency distributions were used as models: Poisson distribution and negative binomial distribution. Then, the theoretical frequency models obtained in the field were compared using chi-square statistical test.

The aggregation indices used to verify the degree of aggregation of the E. meditabunda were: variance/mean ratio and the Morisita and $\mathrm{K}$ indexes (Fernandes et al., 2018), while the theoretical frequency distributions used do evaluate the spatial distribution were: Poisson and negative binomial distributions, according to the methodology reported by Fonseca et al. (2017).
For visual representation of the statistical models, surface maps of the total number of individuals collected during the evaluations were interpolated using the Inverse Distance Weighted (IDW) method with the Software ArcGis ${ }^{\circledR}$. The map described the density of stink bugs (nymphs, adults and nymphs + adults) in the experimental field.

\section{Results}

\section{Temporal variation of E. meditabunda}

Throughout this study, 60 nymphs and 110 adults were counted (Fig. 1). Assessments were carried out from seedling emergence until the first appearance of bolls, but the occurrence of $E$. meditabunda was observed only during the reproductive stage of cotton, comprising the interval between 55 and 91 Days After the Emergence (DAE), with higher occurrence when the first flowers appeared at 70 DAE and a decrease in subsequent evaluations (77, 84, and $91 \mathrm{DAE}$ ), and disappearance after $91 \mathrm{DAE}$. Therefore, these insects are colonizing and feeding on cotton, mainly in the reproductive period of this crop, demonstrating to be a preferred host plant for $E$. meditabunda during this period.

\section{Dispersion Indices}

Aggregation indices, variance-to-mean ratio (I), Morisita index

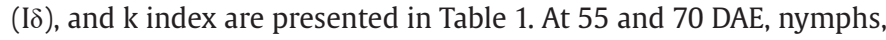
adults, and the total population (nymph + adult) of E. meditabunda had an aggregated distribution based on the variance-to-mean ratio and Morisita Index, while a random pattern was observed in the other evaluations.

Based on the $\mathrm{k}$ values of the negative binomial (Table 1 ), the evaluations at 55, 70, 77 (Adults), 84, 91 DAE (Adults and Total of the population) suggested an aggregate pattern, while the distribution of nymphs at 77 and 91 DAE was uniform.

\section{Frequency distribution}

The chi-square values obtained for the E. meditabunda population fit the two models of theoretical frequency distributions (Table 2). Three times for the Poisson distribution (70 DAE for nymphs, adults and total population), and one time for the negative binomial distribution (70 DAE for adults). In ecological statistics, the best fit is represented by the frequency distribution that has the lowest Chi-square $X^{2}$ calculated (Suekane et al., 2018).

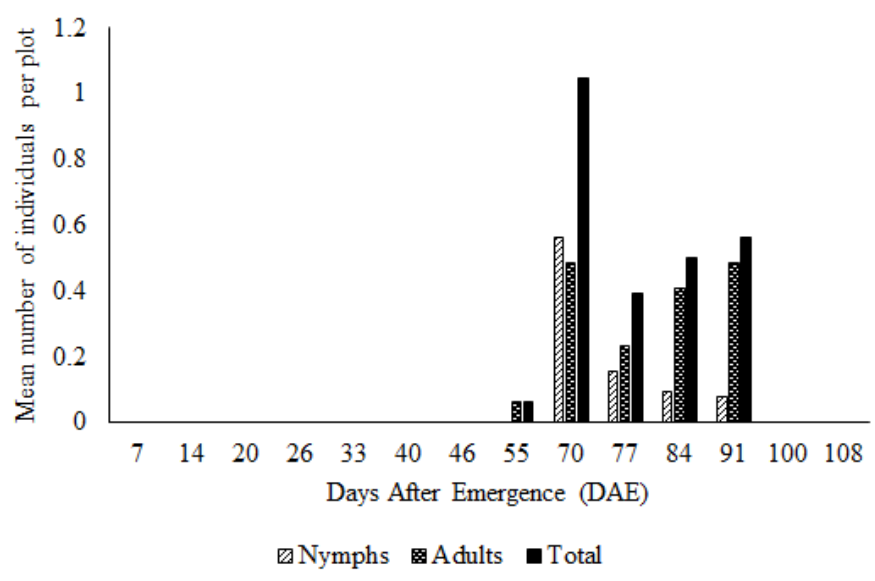

Figure 1 Temporal variation of Edessa meditabunda population in the alternative host plant Gossypium hirsutum (cotton) in experimental Field of Dourados, Brazil. 
Table 1

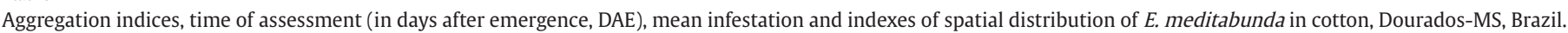

\begin{tabular}{|c|c|c|c|c|c|c|}
\hline DAE & - & $\dot{m}$ & $S^{2}$ & $I$ & $I \delta$ & $k$ \\
\hline \multirow[t]{3}{*}{55} & nymphs & 0 & 0 & - & - & - \\
\hline & adults & 0.062 & 0.091 & $1.460^{*}$ & $10.666^{*}$ & $0.135^{\mathrm{ag}}$ \\
\hline & total $^{* *}$ & 0.062 & 0.091 & $1.460^{*}$ & $10.666^{*}$ & $0.135^{\mathrm{ag}}$ \\
\hline \multirow[t]{3}{*}{70} & nymphs & 0.562 & 1.583 & $2.814^{*}$ & $4.266^{*}$ & $0.309^{\mathrm{ag}}$ \\
\hline & adults & 0.484 & 0.888 & $1.834^{*}$ & $2.752^{*}$ & $0.580^{\mathrm{ag}}$ \\
\hline & total $^{* *}$ & 1.046 & 2.204 & $2.105^{*}$ & $2.055^{*}$ & $0.947^{\mathrm{ag}}$ \\
\hline \multirow[t]{3}{*}{77} & nymphs & 0.156 & 0.133 & $0.857^{\mathrm{ns}}$ & 0 & $-1.093^{\text {un }}$ \\
\hline & adults & 0.234 & 0.277 & $1.184^{\mathrm{ns}}$ & $1.828^{\mathrm{ns}}$ & $1.272^{\mathrm{ag}}$ \\
\hline & total $^{* *}$ & 0.390 & 0.400 & $1.025^{\text {ns }}$ & $1.066^{\mathrm{ns}}$ & $15.388^{\mathrm{al}}$ \\
\hline \multirow[t]{3}{*}{84} & nymphs & 0.093 & 0.118 & $1.259^{\text {ns }}$ & $4.266^{\mathrm{ns}}$ & $0.361^{\mathrm{ag}}$ \\
\hline & adults & 0.406 & 0.435 & $1.072^{\mathrm{ns}}$ & $1.181^{\mathrm{ns}}$ & $5.639^{\mathrm{ag}}$ \\
\hline & total $^{* *}$ & 0.500 & 0.539 & $1.079^{\text {ns }}$ & $1.161^{\mathrm{ns}}$ & $6.300^{\mathrm{ag}}$ \\
\hline \multirow[t]{3}{*}{91} & nymphs & 0.078 & 0.073 & $0.936^{\text {ns }}$ & 0 & $-1.230^{\text {un }}$ \\
\hline & adults & 0.484 & 0.571 & $1.179^{\text {ns }}$ & $1.376^{\mathrm{ns}}$ & $2.702^{\mathrm{ag}}$ \\
\hline & total $^{* *}$ & 0.562 & 0.694 & $1.234^{\mathrm{ns}}$ & $1.422^{\mathrm{ns}}$ & $2.398^{\mathrm{ag}}$ \\
\hline
\end{tabular}

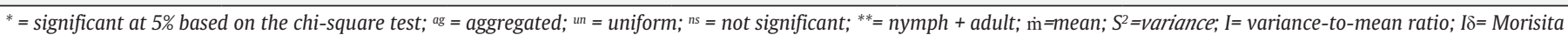
index; $k=k$ index; $X^{2}=$ calculated chi-square.

Table 2

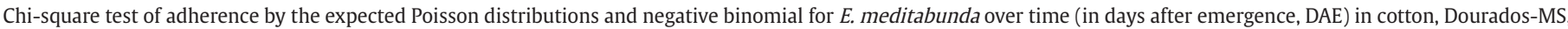
Brazil.

\begin{tabular}{|c|c|c|c|c|c|}
\hline \multicolumn{2}{|c|}{ Samples } & \multicolumn{2}{|c|}{ Poisson } & \multicolumn{2}{|c|}{ Negative Binomial } \\
\hline \multicolumn{2}{|c|}{ DAE } & $X^{2}$ & $\mathrm{DF}$ (nc-2) & $X^{2}$ & DF (nc-2) \\
\hline \multirow[t]{3}{*}{55} & nymphs & - & $i$ & - & $i$ \\
\hline & adults & 0.210 & $i$ & 0.002 & $i$ \\
\hline & total $^{\#}$ & 0.210 & $i$ & 0.002 & $i$ \\
\hline \multirow[t]{3}{*}{70} & nymphs & $19.202^{* *}$ & 2 & $4.644^{\mathrm{ns}}$ & 2 \\
\hline & adults & $8.079^{* *}$ & 1 & $13.207^{* *}$ & 2 \\
\hline & total $^{\#}$ & $19.012^{* *}$ & 3 & $8.354^{\mathrm{ns}}$ & 4 \\
\hline \multirow[t]{3}{*}{77} & nymphs & 0.070 & $i$ & 0.002 & $i$ \\
\hline & adults & $2.212^{\mathrm{ns}}$ & 1 & 0.938 & $i$ \\
\hline & total ${ }^{\#}$ & $1.099^{\text {ns }}$ & 1 & 0.952 & $i$ \\
\hline \multirow[t]{3}{*}{84} & nymphs & 0.101 & $i$ & 0.003 & $i$ \\
\hline & adults & $0.009^{\text {ns }}$ & 1 & 0.043 & $i$ \\
\hline & total $^{\#}$ & $0.652^{\text {ns }}$ & 1 & $0.339^{\text {ns }}$ & 1 \\
\hline \multirow[t]{3}{*}{91} & nymphs & 0.031 & $i$ & 0.001 & $i$ \\
\hline & adults & $0.367^{\text {ns }}$ & 1 & $0.789^{\text {ns }}$ & 1 \\
\hline & total $^{\#}$ & $4.282^{\mathrm{ns}}$ & 2 & $1.376^{\text {ns }}$ & 1 \\
\hline
\end{tabular}

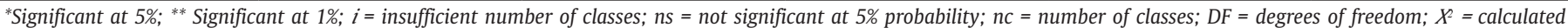
chi-square; \# = nymph + adults.

In the present study, the number of classes of $E$. meditabunda was insufficient to detect the distribution of nymphs at $55,77,84$, and $91 \mathrm{DAE}$, due to their low occurrence in these evaluations.

Thus for adults, the pattern observed adjusted for the Poisson distribution at 70, 77, 84 and 91 DAE. For total of the population, except at 77 DAE (Poisson distribution), the pattern was described by the negative binomial distribution.

Based on dispersion indexes and theoretical frequency distributions, the Poisson model best describes adults infestation of E. meditabunda in cotton, indicating a random distribution $\left(S^{2}=\dot{m}\right)$.

\section{Spatial analysis}

Studies aimed at determining the spatial distribution of insects in cash crops are essential. However, when using only dispersion and frequency distribution indices, just the insect distribution pattern (i.e random, aggregate or uniform) is taken into account, excluding the location of insects in the field, which is obtained by spatial analysis.
The spatial analysis using the IDW method allowed the visualization of the distribution of E. meditabunda nymphs (Fig. 2) and adults (Fig. 3) separately, as well as combined (Fig. 4) throughout time in the cotton field. When examining the distribution pattern of nymphs (Fig. 2), no infestation was observed in cotton plants at 55 DAE. However, at $70 \mathrm{DAE}$ (Fig. 2a), nymphs were observed mainly on the edges, rather than the center of the experimental area in subsequent evaluations (77, 84, 91 DAE). Fig. 2e shows the sum of all nymphs sampled during all evaluations in one map, corroborating the dispersion indices obtained (Table 1), which indicate an aggregated infestation at the beginning, tending to a random distribution over time.

Regarding the pattern of distribution of adults (Fig. 3), at 55 DAE (Fig. 3a), the beginning of infestation is observed as well as the aggregation behavior of E. meditabunda adults. At 70 DAE (Fig. 3b), adults remained aggregated, but also dispersing to the center of the experimental area. After $77 \mathrm{DAE}$ (Fig. 3c), the population dispersed to all cardinal points in the field but did not increase (Fig. 1), and in subsequent evaluations (84 and $91 \mathrm{DAE}$ ), the distribution of adults was random, corroborating the dispersion indices 

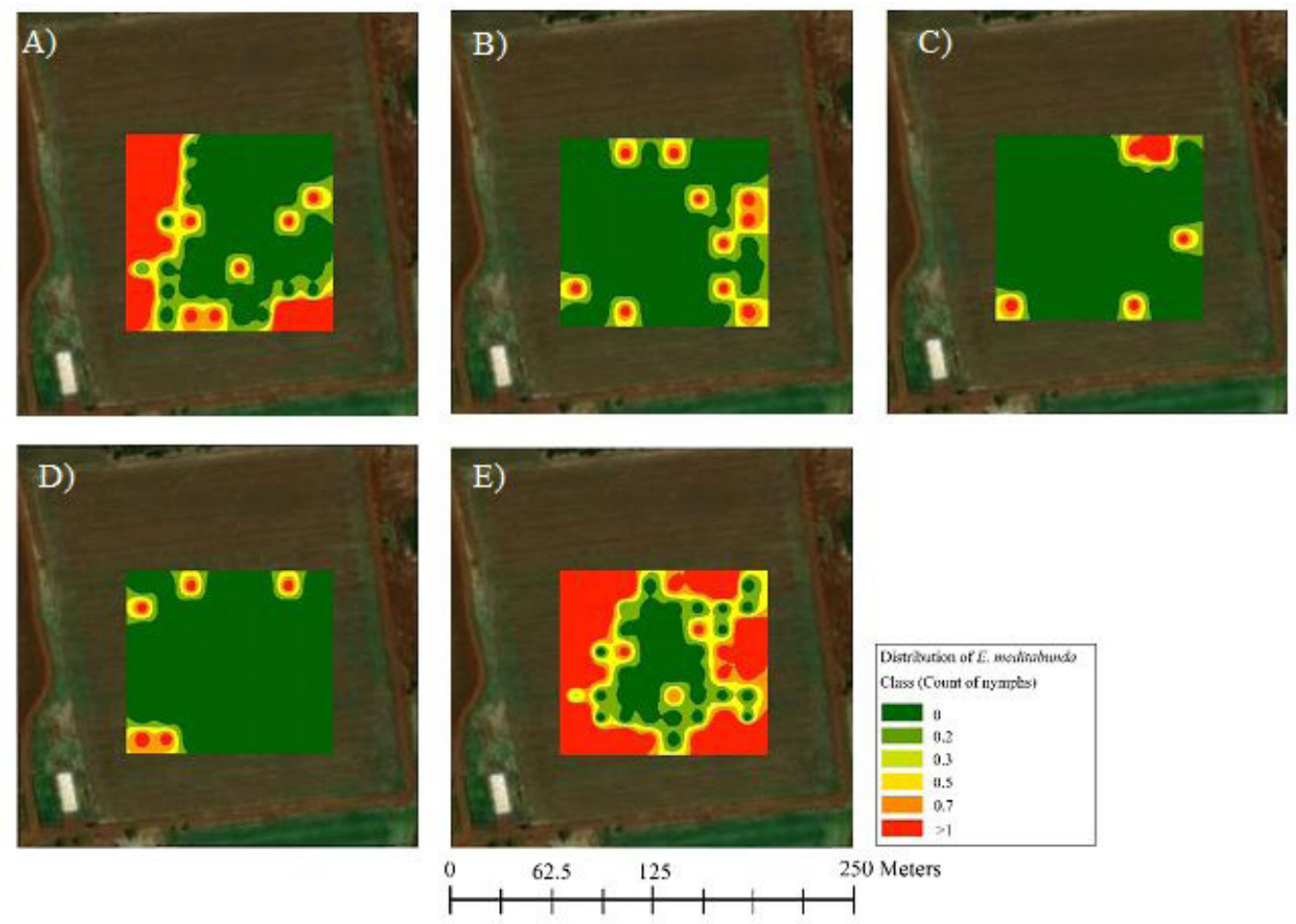

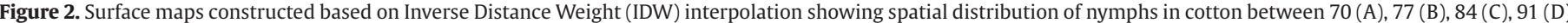
days after emergence (DAE) and Sum of all Evaluations (E). Low density is represented in green while red indicates high density of E. meditabunda.
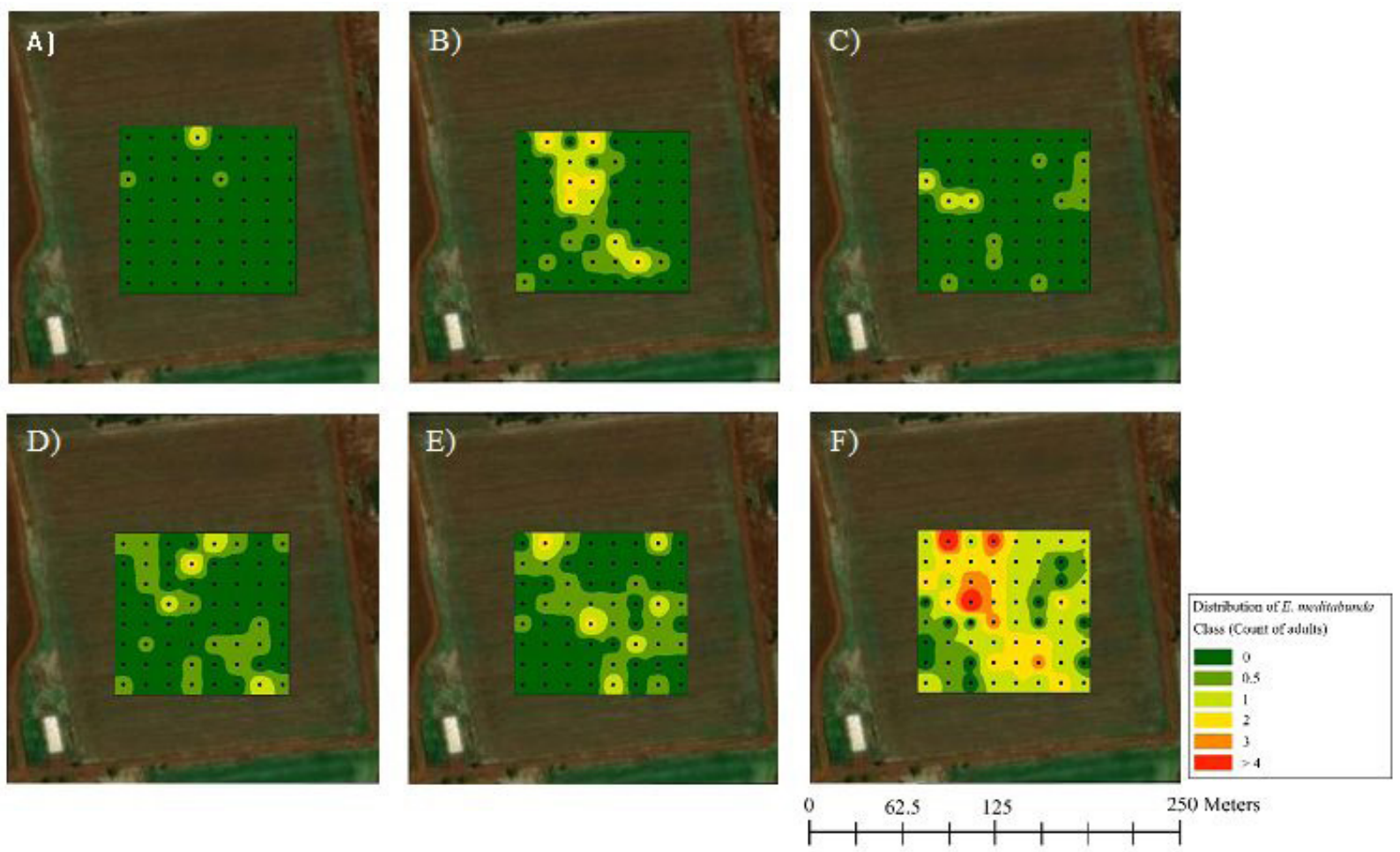

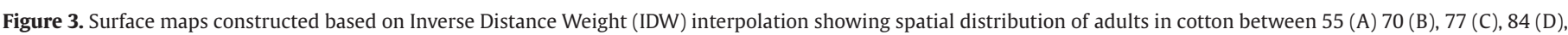
91 (E) days after emergence (DAE) and Sum of all Evaluations (F). Low density is represented in green while red indicates high density of E. meditabunda.

(Table 1 ) and the frequency distribution obtained (Table 2). Also, the analysis of the sum of all adults during all evaluations (Fig. 3f) visually confirmed the random distribution of $E$. meditabunda adults in cotton.

When adding the number of nymphs and adults (Fig. 4) in a single distribution over time, the same behavior of adults is observed, as they comprised most of the sampled population.

\section{Discussion}

In this study, we reported the presence of $E$. meditabunda on cotton plants adjacent to soybeans, demonstrating its potential as a host plant for the colonization and feeding of this stink bug. However, despite its low abundance in this study, this insect may become an 

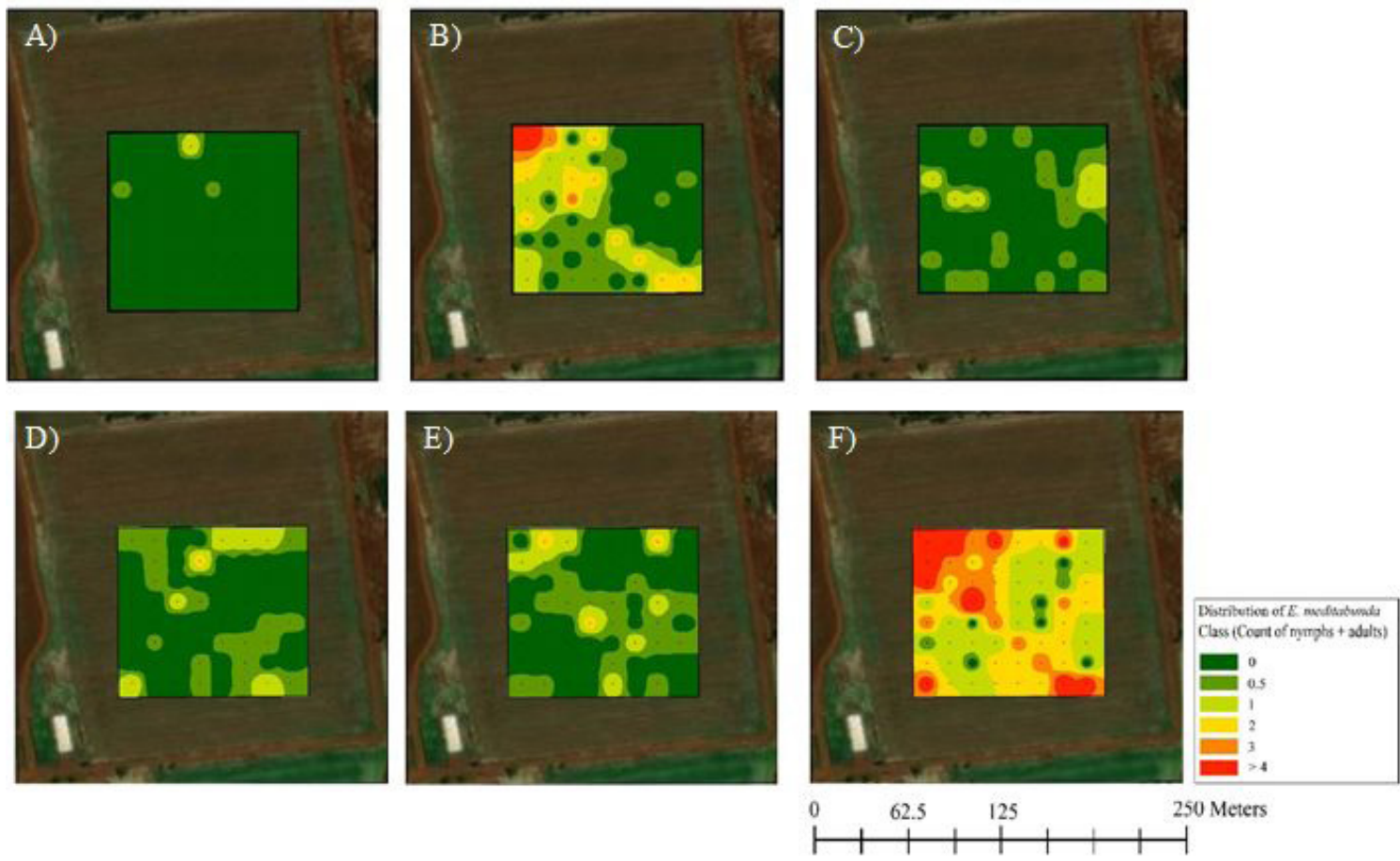

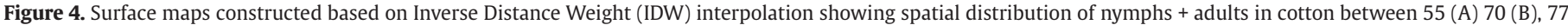
(C), 84 (D), 91 (E) days after emergence (DAE) and Sum of all Evaluations (F). Low density is represented in green while red indicates high density of E. meditabunda.

important pest of cotton in the future. Thus, our study provides a baseline to assess future population changes in cotton. Furthermore, this pest occurred only in the reproductive period of cotton, indicating its preference for cotton squares, flowers, and bolls. Based on the indexes of aggregation and spatial distribution, E. meditabunda presents an aggregated distribution at the beginning of the infestation, tending towards randomness as bolls mature.

\section{Temporal variation of E. meditabunda}

The highest occurrence of $E$. meditabunda at 70 DAE can be explained by the movement of stink bugs from maturing soybean surrounding cotton field. In this evaluation, soybean plants surrounding the experimental area were in the R.8 phenological stage (physiological maturation)(Fehr and Caviness, 1977), corroborating Soria et al. (2009) that reported a greater movement of migratory stink bugs Euschistus heros(Hemiptera: Pentatomidae), E. meditabunda, and Nezara viridula (Hemiptera: Pentatomidae) from soybean to cotton at the same maturation stage of the nearby soybean field. In addition, the absence of nymphs at 55 DAE might be due to the movement of only adults from soybean fields. After reproduction of $E$. meditabunda occurred in the cotton field, occurrence of nymphs was then observed (Souza et al., 2013).

According to Azambuja et al. (2015), both E. meditabunda nymphs and adults can feed and reproduce by consuming cotton leaves and bolls. However, nymph development time slightly increased and longevity of adult females substantially lengthened compared to those fed an artificial diet, thus explaining the decrease in nymphs and the increase in adults throughout evaluations, demonstrating that although reproduction occurs in this host plant, it is not the best food resource for its development.

As bolls matured and entered the cutout stage (physiological maturation), E. meditabunda population probably migrated to other food sources (e.g. Euphorbia heterophylla, Desmodium tortuosum, Crotalaria spp.) as commonly observed in phytophagous stink bugs in search for food, oviposition, and offspring development, responding to changes in the environment and searching for host plants that provide the best conditions to support its population (Panizzi, 1991).

Phytophagous stink bugs have a preference for immature fruits as they are easier to perforate with their oral apparatus, facilitating feeding. Also, these fruits provide better nutrition, thus explaining the population decrease in this study, as cotton bolls ripened (Esquivel, 2011; Medrano et al., 2011).

Bundy and McPherson (2000) observed that phytophagous stink bugs in cotton usually begin an infestation when the first flowers appear until the formation of the first bolls, peaking in abundance when all sizes of developing bolls are available. In addition, Soria et al., (2016), studying the damage caused by $E$. heros in cotton, observed that confined stink bugs fed on leaves, branches, buds, flowers, and bolls. However, they were not able to feed on mature bolls, demonstrating their preference for developing structures, which explains the population dynamics of E. meditabunda throughout the evaluations in this study.

In this study, we describe the dispersal of E. meditabunda during the maturation of soybeans to cotton. Also, the period of appearance of the first bolls is the most susceptible to the establishment of this pest in the crop (Soria et al., 2009). Therefore, cotton plants are alternative hosts for E. meditabunda, providing shelter and food until its optimal host is available, as reported by Soria et al., (2009) and Azambuja et al., (2015).

In addition, with the decreased use of broad spectrum insecticides targeting mainly heliothines, due to the success of Bt cotton technology and boll weevil (Anthonomus grandis) suppression programs, damage to squares and bolls by sap-sucking insects increased as they were no longer indirectly controlled by these control practices (Soria et al., 2009; Lu et al., 2010; Rodrigues et al., 2010).

The importance of stink bugs as cotton pests has been increasing in recent years in Brazil. In this study, we demonstrated the potential of E. meditabunda as a pest of cotton, in which the sucking bug complex is considerably more spatially and temporally variable in damage severity and in abundance, than the consistently severe damage caused by heliothines and boll weevils (Luttrell et al., 2015).

It is also important to emphasize the importance of monitoring the migration of the stink bug complex from soybean crops at the end of the 
soybean crop cycle to cotton plants, mainly because soybean fields cover a significantly larger area compared to that of cotton in Brazil (CONAB, 2020). In addition, it is necessary to take into account other host plants, cultivated or not, which can provide shelter and food during the fallow period.

\section{Dispersion indices}

The beginning of the cotton reproductive period, together with the physiological maturation of soybean, attracted a large concentration of migratory stink bugs arranged in an aggregate pattern in cotton. This inter-crop movement of stink bugs has been reported in several crops (Soria et al., 2009, Reay-Jones et al., 2010, Reeves et al., 2010, Tillman 2011, Reisig et al., 2013).

For subsequent evaluations, however, the population (nymphs + adults) tended to be randomly distributed based on to the variance-to-mean (I) and the Morisita Index (I $\delta$ ), corroborating Weber et al. (2018) findings, on $E$. heros in cotton. These authors observed a tendency toward randomness, after this insect invaded cotton. On the other hand, according to the same authors, a movement of E. heros adults toward an aggregate distribution was observed based on the k index throughout its occurrence in cotton, corroborating this study on $E$. meditabunda.

Fernandes et al., (2018) reported similar results for adults and the total population (nymphs + adults) of phytophagous stink bugs in soybean, where a strong aggregation of these insects was observed, regardless of the variety and system of soybean production. Also, based on the $\mathrm{k}$ index, the distribution of nymphs was aggregate in most evaluations.

\section{Frequency distribution}

As demonstrated by the theoretical frequency distribution, the random pattern best described the arrangement of E. meditabunda, revealing the tendency of these insects to disperse and search for new suitable food sources in cotton (Suekane et al., 2018), after a large initial aggregate movement from soybean.

The movement and, therefore, the spatial distribution of insects can occur when there is a reproductive response to meteorological changes such as temperature, humidity, wind and light, aggregation pheromones or presence of neighboring host plants and the availability of new food sources (Tillman and Cottrell, 2016; Weber et al., 2018).

Thus, the majority of the population consisted of adults (65\%), the decrease in the number of nymphs over time, and the random distribution of E. meditabunda indicate that despite providing the conditions for reproduction, cotton is not a viable host but rather an alternative temporary host for the absence of soybean.

Fonseca et al. (2017) found an aggregate pattern for nymphs and adults of $E$. meditabunda in transgenic soybean with resistance to caterpillars (Bt soybean expressing the Cry1Ac protein); while in non-Bt culture, nymphs and adults of the species were uniformly distributed after emergence, but aggregate afterwards. The population peak of this species occurred in the soybean reproductive stage.

This study is in agreement with Souza et al. (2013) that reported a distribution for the total population of E. heros (adults + nymphs) varying from moderately aggregate to random. Therefore, when the spatial pattern is random, any sample size unit is equally efficient to describe population distribution, with efficiency defined by the number of sample points. A large number of samples is always recommended for randomly distributed populations (Fernandes et al., 2003).

The present study described the occurrence and the spatial distribution of $E$. meditabunda in cotton as a framework to assist in the decision making process of the control of this pest, such as defining sampling points (number and distribution of points). It also provided the basis for the development of a sequential sampling plan to reduce sampling time and increase the reliability of results (Grigolli et al., 2012).
Moreover, the conventional field-based monitoring may become less viable in the future, especially in regions where labor is limited and in large-scale operations (Allen, 2014).

\section{Spatial analysis}

The areas with the highest densities of infestation of $E$. meditabunda nymphs and adults were identified with the aid of distribution maps. Nymphs were observed mainly on the edges of the experimental area throughout the evaluations, while adults occurred initially on the edges, then dispersed throughout the experimental area, mainly in the center. The results obtained in this study are in agreement with those obtained by Weber et al. (2018) that described an initial infestation by $E$. heros on the edges in cotton, then tended to disperse to the center of the experimental area over time.

The movement of E. meditabundaadults from the edges to the center might be associated to the phenological stage of the cotton. As bolls ripened, they became less suitable for the development of $E$. meditabunda, forcing the dispersion of insects in search of new food sources (Reisig et al., 2015).

Our findings suggest the control of $E$. meditabunda only on the edges of cotton fields in the beginning of the infestation. However, pest control in the entire area is needed as the population increases and its distribution became random after the first evaluations of this study.

Information on the spatial distribution is the first step to assist in the decision-making process to control this insect-pest in order to recommend the application of insecticides when necessary and in specific areas of the field. In addition to this study, future research should be carried out for other stink bugs in the soybean/cotton agroecosystem, as well as monitoring the population of these insects in other host plants and native vegetation, aiming to understand the farmscape ecology of stink bugs in time and space, and improving strategies of population control of phytophagous stink bugs.

\section{Conclusion}

In cotton, E. meditabunda occurred when plants were in the reproductive stage. Based on aggregation indices, the spatial distribution of nymphs and adults was aggregated at the beginning of the infestation, but tended toward randomness as bolls matured. Regarding the theoretical frequency distribution, the occurrence of this pest in cotton was best described by the Poisson Distribution.

When monitoring cotton, the migration of E. meditabunda coming from soybean at the end of the cycle must be taken into account, because at this time the latter may serve as a source for new infestations in cotton.

In addition, with the introduction of new technologies and intensification of soybean cultivation, E. meditabunda and other stink bugs can cause further damage to cotton.

\section{Acknowledgments}

We thank UFGD and FAECA/UFGD for logistical support and aid in cultural management.

\section{Conflicts of interest}

The authors declare no conflicts of interest.

\section{Author contribution statement}

RAS and PED contributed with experimental design and manuscript writing; RAS, MDCP and EPS contributed with collected field data and data analysis. All authors read, revised, and approved the manuscript. 


\section{References}

Allen, C. T. , 2014. Integrated pest management in the southern United States of America: changing technology and infrastructure-Implications for the future. In: Peshin, R., Pimentel, D. (Eds.), Integrated Pest Management, Experiences with Implementation, Global Overview. Vol. 4, Springer, New York. pp. 99-152.

Azambuja, R., Degrande, P. E., Souza, E. P., Fagundes Pereira, F., Pastori, P. L., 2015. Reproduction of Edessa meditabunda (Hemiptera: Pentatomidae) on Cotton. Acta Biol. Colomb. 20 (2), 203-208.

Bundy, C. S., McPherson, R. M., 2000. Dynamics and seasonal abundance of stink bugs (Heteroptera: Pentatomidae) in a cotton-soybean ecosystem. J. Econ. Entomol. 93 (3), 697-706.

Companhia Nacional de Abastecimento - CONAB, 2020. Acompanhamento da safra brasileira: grãos, terceiro levantamento. Safra 2020/2021. Vol. 8. CONAB, Brasília, p. 12-18. Available in: https://www.conab. gov.br/info-agro/safras/graos/boletim-da-safra-de-graos (accessed 1 January 2021).

Esquivel, J. F., 2011. Estimating potential stylet penetration of southern green stink bug-a mathematical modeling approach. Entomol. Exp. Appl. 140 (2), 163-170.

Farias, P. R. S., Barbosa, J. C., Busoli, A. C., 2001. Amostragem sequencial (presença-ausência) para Spodoptera frugiperda (J.E. Smith) (Lepidoptera: Noctuidae) na cultura do milho. Neotrop. Entomol. 30 (4), 691-695.

Fehr, W. R., Caviness, C. E., 1977. Stages of Soybean Development. Iowa Agricultural and Home Economics Experiment Station. Iowa State University, Ames. (Special report, 80).

Fernandes, M. G., Costa, E. N., Cavada, L. H., Mota, T. A., Fonseca, P. R. B., 2018. Spatial distribution, and sampling plan of the phytophagous stink bug complex in different soybean production systems. J. Appl. Entomol. 143 (3), 236-249.

Fernandes, O. D., Parra, J. R. P., Ferreira Neto, A., Pícoli, R., Borgatto, A. F., Demétrio, G. B., 2003. Efeito do milho geneticamente modificado (MON810) sobre a lagarta-do-cartucho Spodoptera frugiperda (J.E. Smith, 1797) (Lepidoptera: noctuidae). Rev. Bras. Milho Sorgo 2 (1), 25-35.

Fonseca, P. R. E. B., Fernandes, M. G., Justiniano, W., Cavada, L. H., Viana, C. A. L. T. P., Silva, J. A. N., 2017. Spatial distribution of adults and nymphs of stink bug, Edessa meditabunda (Fabricius, 1974) (Hemiptera: Pentatomidae) on soybean Bt and non-Bt. Afr. J. Agric. Res. 12 (40), 3013-3023.

Freire, E. C. 2015. Algodão no Cerrado do Brasil, 3. ed. Gráfica e Editora Positiva, Brasília.

Grigolli, J. F. J., Souza, L. A., Fraga, D. F., Busoli, A. C., 2012. Boll weevil feeding preference on squares at different ages and square shedding time of cotton cultivars. Afr. J. Agric. Res. 7 (30), 4317-4323.

Haney, P. B., Lewis, W. J., Lambert, W. R., 2009. Cotton production and the boll weevil in Georgia: history, cost of control, and benefits of eradication. In College of Agricultural and Environmental Sciences, University of Georgia. Research Bulletin of the Georgia Agricultural Experiment Stations. University of Georgia, Athens.

Lu, Y., Wu, K., Jiang, Y., Xia, B., Li, P., Feng, H., Guo, Y., 2010. Mirid bug outbreaks in multiple crops correlated with wide-scale adoption of Bt cotton in China. Sci. 328 (5982), 1151-1154.

Luttrell, R. G., Teague, T. G., Brewer, M. J., 2015. Cotton Insect Pest Management. American Society of Agronomy, Crop Science Society of America, Soil Science Society of America, Madison. (Cotton, Agronomy Monograph, 57).

Medrano, E. G., Esquivel, J. F., Bell, A. A., 2007. Transmission of cotton seed and boll rotting bacteria by the southern green stink bug (Nezara viridula L.). J. Appl. Microbiol. 103 (2), 436-444.

Medrano, E. G., Esquivel, J. F., Bell, A. A., Greene, J. K., Roberts, P. M., Bacheler, J. S., Marois, J. J., Wright, D. L., Nichols, R. L., 2011. Analysis of microscopic injuries caused by southern green stink bug (Hemiptera: Pentatomidae) feeding on cotton bolls. Southwest. Entomol. 36 (3), 233-245.
Olson, D. M., Ruberson, J. R., Zeilinger, A. R., Andow, D. A., 2011. Colonization preference of Euschistus servus and Nezara viridula in transgenic cotton varieties, peanut, and soybean. Entomol. Exp. Appl. 139 (2), 161-169.

Panizzi, A. R. 1991. Ecologia nutricional de insetos sugadores de sementes, In: Panizzi, A. R., Parra, J. R. P. (Eds.), Ecologia nutricional de insetos e suas implicações no manejo de pragas. Manole., São Paulo, pp. 253-287.

Panizzi, A. R., 2015. Growing problems with stink bugs (Hemiptera: Heteroptera: Pentatomidae): species invasive to the US and potential neotropical invaders. Am. Entomol. (Lanham Md.) 61 (4), 223-233.

Reay-Jones, F. P. F., Greene, J. K., Toews, M. D., Reeves, R. B., 2009. Sampling stink bugs (Hemiptera: Pentatomidae) for population estimation and pest management in southeastern cotton production. J. Econ. Entomol. 102 (6), 2360-2370.

Reay-Jones, F. P. F., Toews, M. D., Greene, J. K., Reeves, R. B., 2010. Spatial Dynamics of Stink (Hemiptera: Pentatomidae) and Associated Boll Injury in Southeastern Cotton Fields. Environ. Entomol. 39 (3), 956-969.

Reeves, R. B., Greene, J. K., Reay-Jones, F. P. F., Toews, M. D., Gerard, P. D., 2010. Effects of adjacent habitat on populations of stink bugs (Heteroptera: Pentatomidae) in cotton as part of a variable agricultural landscape in South Carolina. Environ. Entomol. 39 (5), 1420-1427.

Reisig, D. D., Reay-Jones, F. P. F., Meijer, A. D., 2015. Aggregation and association of NDVI, boll injury, and stink bugs in North Caroline cotton. J. Insect Sci. 15 (1), 1-4.

Reisig, D. D., Roe, M., Dhammi, A., 2013. Dispersal pattern and dispersion of adults and nymph stink bugs (Hemiptera: Pentatomidae) in wheat and corn. Environ. Entomol. 42 (6), 1184-1192.

Rodrigues, T. R., Fernandes, M. G., Santos, H. R. D., 2010. Distribuição espacial de Aphis gossypii (Glover) (Hemiptera, Aphididae) e Bemisia tabaci (Gennadius) biótipo B (Hemiptera, Aleyrodidae) em algodoeiro Bt e não-Bt. Rev. Bras. Entomol. 54 (1), 136-143.

Soria, M. F., Degrande, P. E., Panizzi, A. R., 2010. Maior incidência de percevejos fitófagos na cultura do algodão. Cultivar. 131 (4), 18-20.

Soria, M. F., Degrande, P. E., Panizzi, A. R., Toews, M. D., 2016. Economic injury level of the neotropical brown stink bug Euschistus heros (F.) on cotton plants. Neotrop. Entomol. 46 (3), 324-335.

Soria, M. F., Thomazoni, D., Martins, R. R., Degrande, P. D., 2009. Stink bugs incidence on Bt cotton in Brazil. In: Beltwide Cotton Conferences, 2009, San Antonio, Texas, EUA. Proceedings. Washington: National Cotton Council of America.

Sosa-Gómez, D. R., Corrêa-Ferreira, B. S., Kraemer, B., Pasini, A., Husch, P. E., Delfino Vieira, C. E., Negrão Lopes, I. O., 2019. Prevalence, damage, management and insecticide resistance of stink bug populations (Hemiptera: Pentatomidae) in commodity crops. Agric. For. Entomol. 22 (2), 99-118.

Souza, L. A., Barbosa, J. C., Grigolli, J. F. J., Fraga, D. F., Maldonado, W., Busoli, A. C., 2013. Spatial distribution of Euschistus heros (F.) (Hemiptera: Pentatomidae) in soybean. Neotrop. Entomol. 42 (4), 412-418.

Suekane, R., Degrande, P. E., Melo, E. P. D., Azambuja, T. M., Menegati, C. T., 2018. Spatial distribution of soybean plants infested with whitefly Bemisia tabaci (Gennadius, 1889) (Hemiptera: aleyrodidae). Arq. Inst. Biol. (Sao Paulo) 85, 1-6.

Tillman, P. G., 2011. Influence of corn on stink bugs (Heteroptera: Pentatomidae) in subsequent crops. Environ. Entomol. 40 (5), 1159-1176.

Tillman, P. G., Cottrell, T. E., 2016. Attraction of Stink Bug (Hemiptera: Pentatomidae) Nymphs to Euschistus Aggregation Pheromone in the Field. Fla. Entomol. 99 (4), 678-682.

Weber, A. C., Degrande, P. E., Souza, E. P., Azambuja, R., Fernandes, M. G., 2018. Spatial distribution of Euschistus heros (Hemiptera: Pentatomidae) in cotton (Gossypium hirsutum Linnaeus). An. Acad. Bras. Cien. 90 (4), 3483-3491. 